\title{
CALCINED PHOSPHATIC LIMESTONE AS A FERTILIZER ${ }^{\prime}$
}

\author{
E. VAN ALSTINE \\ New Jersey A gricultural Experiment Stations \\ Received for publication, Nov. 1, 1921 \\ INTRODUCTION
}

Before presenting experimental data it may be well to indicate the extent to which phosphatic limestone occurs, the quantities of phosphate held in it, and the significance which would attach to a method for profitable utilization of this source of phosphatic fertilizer.

RELATION BETWEEN PHOSPHATIC LIMESTONE AND PHOSPHATE ROCK

The brown phosphatic limestone from central Tennessee consists essentially of nodules of apatite varying in size from very fine dust to particles that will not pass a 20 -mesh sieve, held together by a matrix of limestone, principally calcium carbonate. Where conditions have been favorable, the carbonates have been removed through solution in carbonated water and the much less soluble tricalcium phosphate is left but little affected except for the inevitable rounding off of sharp corners during the weathering process and except, also, for the deposition upon their surfaces of iron and aluminum oxides. This iron and aluminum existed in small amounts in the rock from which the phosphate has separated and the result of the weathering has been, through the removal of lime carbonate, a concentration, not only of the lime phosphate, but also of the iron and aluminum. Other substances, such as silica, which existed in the limestone and which are but slightly soluble in ground water remain mixed with the phosphate rock and reduce the tricalcium phosphate content to about 80 per cent or less. It sometimes happens, after the "brown rock" has been liberated from the limestone and concentrated, that it is more or less loosely bound together again by some cementing material which causes it to cohere in chunks of varying degrees of hardness when mined. These chunks will hold together well enough so that they can be built into piles over wood which is burned for the purpose of driving off moisture. Very much of the brown phosphate rock, however, exists as a loose granular deposit which forms a mud with water and which is easily removed from the ground with a shovel.

\footnotetext{
1 Paper No. 43 of the Journal Series, New Jersey Agricultural Experiment Stations, Department of Soil Chemistry and Bacteriology.

This paper will appear in Rotgers College Studies, vol. 1.
} 
Just why and how this phosphatic material came to be deposited with the limestone has not been definitely learned though it is supposed to have originated from the remains of some form or forms of marine life, but, since all known deposits of "brown rock" in central Tennessee have come from phosphatic limestone, these deposits, however extensive they may be, can exist only where conditions have been favorable for the dissolving action of ground water without the removal of phosphate material by erosion. Naturally, then, these deposits are limited in extent in comparison with the original limestone formation and, as a matter of fact, they are very limited in comparison with the still existing deposit of phosphatic limestone.

In many places the over burden of soil and rock has been so thick or so impervious, or has in other ways so protected the phosphatic limestone that it has not permitted this leaching. This condition still exists over extensive areas of the central basin of Tennessee and a study of any geological map of the area will show how extensive is this geological formation. Under this condition the phosphatic limestone may be covered by a thick layer of soil and rock or it may lie near the surface.

There are still other large areas where, during the most recent geological years, extending to the present time, erosion has been more than keeping pace with the removal of limestone by leaching. Where this erosion has not been so extensive as to remove the limestone itself in addition to what phosphate rock may have been liberated, the phosphatic limestone is left at or near the surface. A geological map shows that areas of this nature are also much more extensive than are the areas of workable deposits. It may reasonably be that the overlying strata have protected much of this limestone from leaching so that very little phosphate has been liberated. In this case the limestone has remained nearly or quite intact while it has continued to be uncovered by erosion.

In addition to the areas which exist under these two general conditions, there is also a considerable amount of phosphatic limestone which exists in or together with the workable deposits of phosphate rock. Rarely ever has the solution of limestone been complete. Even in those places where there are the best deposits of brown phosphate rock there exist unleached boulders and ledges of limestone termed "chimneys" or "horses" by the miners. Figure 1 shows the appearance of this limestone in a mine near Columbia, Tennessee after the phosphate rock had been removed.

The quantity and extent of the phosphatic limestone is many times greater than that of the phosphate rock. The quantity of phosphorus still locked up in the limestone in excess of that found in the rock phosphate deposits is roughly proportional to the excess of area still occupied by the phosphatic limestone over that occupied by the phosphate rock deposits.

Although new deposits of phosphate rock are still being found and opened up, the demand for the product has increased to such an extent that the methods of mining and purifying the phosphate have several times been improved to recover larger and larger percentages of the deposit. 
PATENTS FOR THE UTILIZATION OF PHOSPHATIC IIMESTONE

Two patents (no. 971830 and no. 13302) aiming at the utilization of phosphatic limestone for fertilizer purposes have been taken out in this country. The plan of these patents is to make the phosphorus available to plants by burning phosphatic limestone at a temperature sufficiently high to drive off carbon dioxide and then slaking to break up the mass into a fine state of division. It has been claimed that this treatment, by breaking the phosphate nodules into a very fine state of division would make the phosphorus available.

More recently (2) a very similar German patent, no. 321776 , has been granted. In this case a mixture of limestone and phosphate rock is burned.

Since limestone, heated to a temperature sufficient to drive off carbon dioxide slakes readily and reduces to a very fine powder, it remains only to determine how the phosphate in the phosphatic limestone is affected; to find out whether this too is pulverized, made porous or in any way made more available to plants.

During the summer of 1920 visits were made to a number of the worked phosphate deposits of central Tennessee and samples of phosphatic limestone were taken from several localities where there seemed to be an abundant supply of it easily accessible.

\section{METHODS}

In accordanice with the method oulined in the American patents, quantities of these samples were broken into small pieces having a thickness of two inches or less and burned for ten hours at the full heat of a good gas furnace capable of holding six or eight pounds of the limestone when piled loosely with the muffle removed. The muffle was replaced by thin fire brick so that there was a reverbratory action of the flame. At the end of ten hours the lime was removed from the furnace and water was added to it while it was still hot and would slake readily. Only enough water was added to leave a comparatively dry powder when the slaking was complete.

This material, used in the tests reported below, was, for convenience, designated in the tables by the abbreviation HP and for brevity in discussions has been termed "hydrophos."

Under the treatment given, practically all of the carbon dioxide was driven off, as acid test showed, and the whole rock was reduced to what appeared from a superficial examination to be only hydrated lime. A sifting test showed, however, that a certain amount of it would not pass a 40-mesh sieve. One sample which had received the above treatment was rubbed well in a mortar with a rubber pestle. A sifting test of this showed about 12 per cent of the entire weight to be held on a 40 -mesh sieve, 42 per cent on 100-mesh sieve, 18 per cent on a 200 -mesh sieve and 28 per cent passing a 200 -mesh sieve. Microscopical examination of the granules held on each of the sieves showed them to be coated with much finer particles of hydrated lime. 
Another sample, after burning and slaking, was sifted and analyzed for the phosphorus content of the different separates. The results of the sieving and the analyses are shown in table 1 from which it may be seen that the composite sample after burning and slaking contained 23.5 per cent $\mathrm{P}_{8} \mathrm{O}_{3}$ equivalent to 51.35 per cent $\mathrm{Ca}_{8}\left(\mathrm{PO}_{4}\right)_{2 .}{ }^{2}$

Microscopical examination in this case also showed hydrated lime adhering to all of the granules and yet the separates which did not pass a 100-mesh sieve contained more than one-half of the total phosphorus. The finer granules present a larger surface per unit weight to which hydrated lime may adhere.

TABLE 1

Sicving lests and phosphatic content of the separates from a sample of burned and hydrated phosphatic limestone

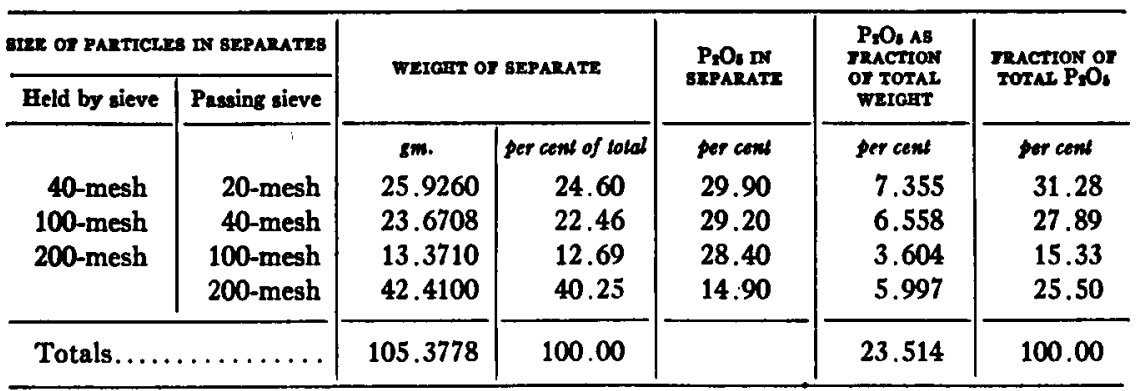

TABLE 2

Analysis of granular separate from burned and hydrated phosphatic lime-stone held on a 200mesh sieve and thoroughly washed to remove free lime

\begin{tabular}{|c|c|}
\hline CONBIITUENT & CONTENT \\
\hline 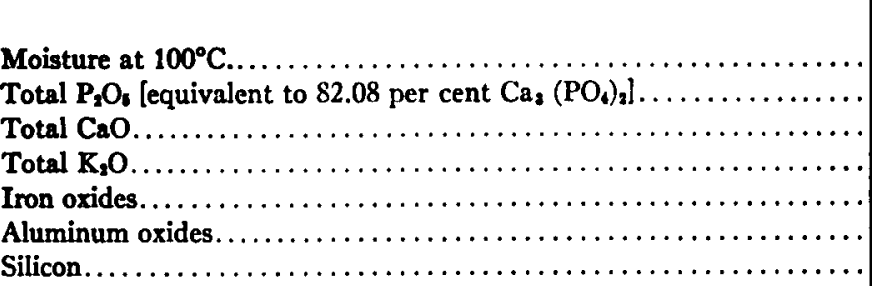 & $\begin{array}{r}\text { tor and } \\
0.03 \\
37.60 \\
52.00 \\
\text { Trace } \\
0.40 \\
0.79 \\
\text { Trace }\end{array}$ \\
\hline
\end{tabular}

This is probably sufficient to explain the fact that the finer separates contain a higher percentage of lime and a lower percentage of phosphoric acid. The separate passing the 200 -mesh sieve, of course, contained a very large amount of hydrated lime not adhering to phosphatic granules. Evidently there has been little, if any, pulverizing of phosphate granules by the process of treatment, for the phosphoric acid passing a 200-mesh sieve was but one-fourth of the entire quantity, an amount which may well have existed as granules of this degree of fineness in the untreated limestone.

'Chemical analyses, unless otherwise stated, were made by Wiley \& Co., commercial chemists located in Baltimore, Md. 
A sample of the burned and hydrated product passing a 40-mesh sieve and held by a 200-mesh sieve, after thorough washing and repeated rubbing with a soft rubber pestle to remove as much of the fine lime as possible, when dried and pulverized to pass a 100 -mesh sieve, showed an analysis of 37.6 per cent of $\mathrm{P}_{2} \mathrm{O}_{5}$ which is equivalent to 82.08 per cent of tricalcium phosphate. This product has been designated by the abbreviation TP ("thermophos") and was used in series $\mathrm{A}$ of the following tests. A partial analysis of it showed the results presented in table 2 .

Microscopical and chemical examination of samples of burned and hydrated phosphatic limestone revealed no difference due to differences in the length of time of burning, so long as the temperature was high enough and maintained long enough to drive off all of the carbon dioxide.

\section{CULTURE EXPERIMENTS}

Chemical and microscopical tests all giving negative results on the value of the material, it remained for culture experiments to show what results might be expected from its field use.

\section{Sand Cultures, Series $A$}

It was thought that results from sand cultures might be influenced less by factors not under control. Accordingly 138 cultures were prepared in 1-gallon stone jars holding $5 \mathrm{kgm}$. quartz sand which had been washed with running water to remove fine material, rinsed with distilled water and finally air dried. This sand had a water holding capacity of 24.48 per cent of the weight of the dry sand and during the growing period of the cultures the moisture content of the sand was kept close to 60 per cent of its water holding capacity (733 cc. per jar) by frequently weighing and adding the necessary amount of distilled water. Six of the cultures were treated with sulfur without beneficial effect and are not reported here.

Soy beans of the Edna variety were transplanted to these jars, six plants to a culture on October 30,1920. The number of plants per jar was reduced to three on November 30 and the final harvest was made on December 29. Weights were taken on the plants harvested November 30 , but the results showed no significance which was not more strikingly shown in the results of the second harvest and, therefore, will not be reported.

On December 8, about six weeks after planting, solution was drawn from the bottom of each jar and its hydrogen-ion concentration determined by the colorimetric method. The $\mathrm{pH}$ values obtained varied from 5.0 to 8.5 , but there was no relation between these values and yields or availability of the phosphate fertilizers.

With the following explanations the treatment of each of the cultures, as indicated in table 4 and the accompanying foot notes, will be easily understood. Except for the last 8 cultures (131-138), all the essential plant food 
elements were added in the form of salts in solution. The salts used and the quantities of half molecular solutions per liter of the $733 \mathrm{cc}$. of moisture added to each jar at the beginning of the experiment were as shown in table 3.

The quantities of salts used and the volume of water added at the beginning were such as to make a solution having an osmotic pressuse value of about two atmospheres.

As a basis for the quantities of phosphorus to be applied, acid phosphate analyzing 17.8 per cent total $\mathrm{P}_{2} \mathrm{O}_{5}$ was applied in four different quantities equivalent to $200,500,1000$ and 2000 pounds per $2,000,000$ pounds of sand. Where phosphate fertilizers of other forms were used they were added in quantities which would supply the same amounts of phosphorus.

Burned and hydrated phosphatic limestone pulverized to pass a 100-mesh sieve contained 23.85 per cent of total $\mathrm{P}_{2} \mathrm{O}_{6}$ and 33.5 per cent of $\mathrm{Ca}(\mathrm{OH})_{2}$ while the product obtained by sifting the unpulverized hydrated product through a 200-mesh sieve contained 13.76 per cent $\mathrm{P}_{2} \mathrm{O}_{6}$ and 51.29 per cent of $\mathrm{Ca}(\mathrm{OH})_{2}$. For the purpose of comparison certain cultures without phosphorus and certain

TABLE 3

Nutrient salts and the amounts used in the sand cultures with soy beans

\begin{tabular}{|c|c|c|}
\hline NUTRIENT SALTS USED & $\begin{array}{l}\text { O.5 Y BOLUTION } \\
\text { PER ITTRR OI } \\
\text { BOLUTTON ADDED } \\
\text { AT START }\end{array}$ & $\begin{array}{c}\text { WIIOHT of SALTS } \\
\text { PKR JAR }\end{array}$ \\
\hline 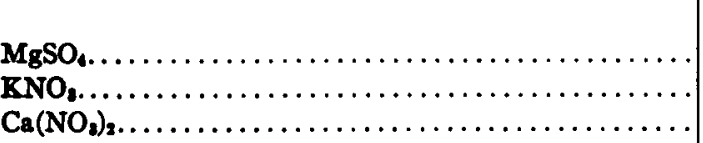 & $\begin{array}{r}c . c . \\
40.60 \\
34.84 \\
5.08\end{array}$ & $\begin{array}{l}8 m . \\
1.79 \\
1.29 \\
0.31\end{array}$ \\
\hline
\end{tabular}

others with each of the forms of phosphate fertilizers other than the above were treated with hydrated lime in amounts equal to those contained in corresponding treatments with the above phosphate products. These facts are indicated in table 4 by the abbreviations $\mathrm{HL}^{1}-\mathrm{HL}^{4}$ and $\mathrm{HL}^{5}-\mathrm{HL}^{8}$.

Calcium cabonate in the form of a high grade limestone pulverized to pass a 100-mesh sieve and in amounts equal to those found in the four quantities of pulverized phosphatic limestone used, was added to some of the jars without posphorus and to some of the jars receiving each of the other forms of phosphatic fertilizers except burned phosphatic limestone ("HP").

As a check to see whether or not the burning of rock phosphate would cause it to have the same effect upon crop production that the burning might cause the phosphate in the limestone to have, a quantity of floats was burned for 10 hours at a temperature of about $800^{\circ}-1000^{\circ} \mathrm{C}$. and used in comparison with the other phosphates.

Since there seemed to be but little, if any, difference in yields when different quantities of the same phosphate materials have been used, yields for the treatments with the same materials have been averaged together as reported in table 4. 
The probable error (1) of the relative yield values in tables 4 and 5 has been calculated in each case upon original weights of individual plants by the formula

$$
\text { p.e. }=0.6745 \frac{d^{2}}{n(n-1)}
$$

The probable error of the percentage increases has been calculated in each case upon original weights by the formula for probable error of difference

$$
\text { p.e. }=\mathrm{e}^{1}-\mathrm{e}^{2} \pm \sqrt{\left(\mathrm{a}^{1}\right)^{2}+\left(\mathrm{a}^{2}\right)^{2}}
$$

\section{Symbols used in table 4}

$\mathrm{GL}^{2}, \mathrm{GL}^{2}, \mathrm{GL}^{2}, \mathrm{GL}^{4}=$ ground limestone (88.41 per cent $\mathrm{CaCO}_{2}$ ) at rates of $0.1708,0.4270$, 0.8540 and $1.7800 \mathrm{gm}$. per jar furnishing calcium carbonate equal to that added to the jars in $\mathrm{PL}^{1}, \mathrm{PL}^{2}, \mathrm{PL}^{2}, \mathrm{PL}^{4}$ respectively.

$\mathrm{HL}^{1}, \mathrm{HL}^{2}, \mathrm{HL}^{2}, \mathrm{HL}^{4}=$ hydrated lime (97.26 per cent $\mathrm{Ca}(\mathrm{OH})_{2}$ ) at rates of $0.1402,0.3506$, 0.7011 and $1.4023 \mathrm{gm}$. per jar, supplying $\mathrm{Ca}(\mathrm{OH})_{2}$ equal to that added in $\mathrm{HP}^{1}, \mathrm{HP}^{2}, \mathrm{HP}^{\star}$, HPt.

$\mathrm{HL}^{\circ}, \mathrm{HL}^{6}, \mathrm{HL}^{7}, \mathrm{HL}^{8}$ - hydrated lime at rates of $0.5045,1.2612,2.5224$ and $5.0449 \mathrm{grams}$ per jar supplying $\mathrm{Ca}(\mathrm{OH})_{\text {s }}$ slightly in excess of that added in $\mathrm{HP}^{6}, \mathrm{HP}^{\prime}, \mathrm{HP}^{7}, \mathrm{HP}$.

$\mathrm{PL}^{1}, \mathrm{PL}^{2}, \mathrm{PL}^{2}, \mathrm{PL}^{4}=$ phosphatic limestone (21.76 per cent total $\left.\mathrm{P}_{8} \mathrm{O}_{4}\right)$ pulverized to pass a 100-mesh sieve and used in quantities supplying phosphorus equal to that added in AP1, AP', APs, AP4.

$\mathrm{HP}^{1}, \mathrm{HP}^{2}, \mathrm{HP}^{3}, \mathrm{HP}^{4}=$ burned and hydrated phosphatic limestone $(23.85$ per cent total $\mathrm{P}_{5} \mathrm{O}_{\mathrm{B}}$ ) pulverized to pass a 100 -mesh sieve and used in quantities supplying phosphorus equal to that added in $\mathrm{AP}^{1}, \mathrm{AP}^{2}, \mathrm{AP}^{\mathbf{3}}, \mathrm{AP}^{4}$.

HPs, HP', HP7, HP' - the fine separate passing a 200-mesh sieve from burned and hydrated phosphatic limestone (13.76 per cent total $\mathrm{P}_{2} \mathrm{O}_{6}$ ) used in quantities supplying phosphorus equal to that added in $\mathrm{AP}^{1}, \mathrm{AP}^{2}, \mathrm{AP}^{2}, \mathrm{AP}^{4}$.

$T^{1}, T^{2}, T^{2}, T^{4}=$ phosphatic limestone, burned, hydrated, washed on a 200-mesh sieve, elutriated until nearly free from $\mathrm{Ca}(\mathrm{OH})_{2}$, pulverized to pass an 100-mesh sieve (37.6 per cent total $\mathrm{P}_{2} \mathrm{O}_{3}$ ) and used in quantities supplying phosphorus equal to that added in $\mathrm{AP}^{1}, \mathrm{AP}^{\mathbf{2}}, \mathrm{AP}^{\mathbf{4}}, \mathrm{AP}^{4}$.

$R P^{1}, R^{2}, R P^{4}, R^{4}=$ floats $\left(34.1\right.$ per cent total $P_{2} O_{6}$ ) pulverized to pass a 100-mesh sieve and used in quantities supplying phosphorus equal to that added in $\mathrm{AP}^{1}, \mathrm{AP}^{\mathbf{3}}, \mathrm{AP}^{2}, \mathrm{AP}^{4}$.

$R^{\prime}, R^{4}, R^{7}, R^{2}$ = floats passing a 200-mesh sieve (33.25 per cent total $\left.\mathrm{P}_{8} \mathrm{O}_{6}\right)$ used in quantities supplying phosphorus equal to that added in $\mathrm{AP}^{1}, \mathrm{AP}^{2}, \mathrm{AP}^{2}, \mathrm{AP}^{4}$.

$\mathrm{BRP}^{1}, \mathrm{BRP}^{2}, \mathrm{BRP}, \mathrm{BRP}$ - floats (34.94 per cent total $\mathrm{P}_{3} \mathrm{O}_{6}$ ) pulverized to pass a 100 mesh sieve, burned for ten hours at about $800^{\circ}$ to $1000^{\circ} \mathrm{C}$. and used in quantities supplying phosphorus equal to that added in $\mathrm{AP}^{1}, \mathrm{AP}^{2}, \mathrm{AP}^{\mathrm{z}}, \mathrm{AP}^{4}$.

$A P^{1}, A^{2}, A P^{2}, A P^{4}=$ acid phosphate $\left(17.8\right.$ per cent total $\left.\mathrm{P}_{2} \mathrm{O}_{6}\right)$ used at the rates of 200 , 500,1000 and 2000 pounds per 2,000,000 pounds of dry sand.

$\mathrm{BS}^{1}, \mathrm{BS}^{2}, \mathrm{BS}^{2}, \mathrm{BS}^{4}=$ basic slag $\left(18.25\right.$ per cent total $\left.\mathrm{P}_{8} \mathrm{O}_{8}\right)$ used in quantities supplying phosphorus equal to that added in $\mathrm{AP}^{1}, \mathrm{AP}^{2}, \mathrm{AP}^{2}, \mathrm{AP}^{4}$.

\section{Results of Series $A$}

From table 4 it may be observed that all the forms of phosphate produced some increase over growth obtained without phosphorus and without lime in some form, but none of the forms of phosphorus, except acid phosphate and basic slag, produced under any condition more growth than was obtained with ground limestone without phosphorus. 


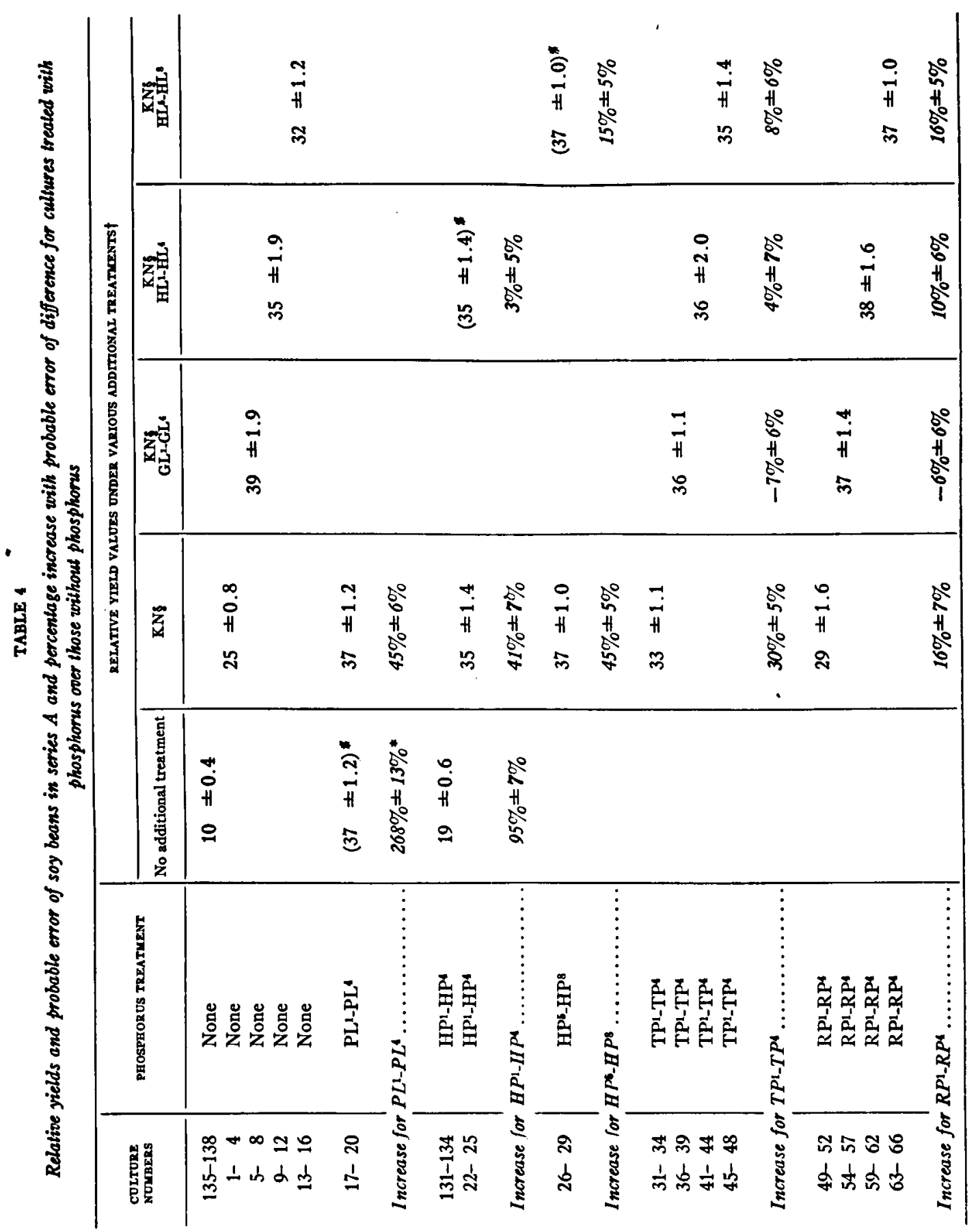




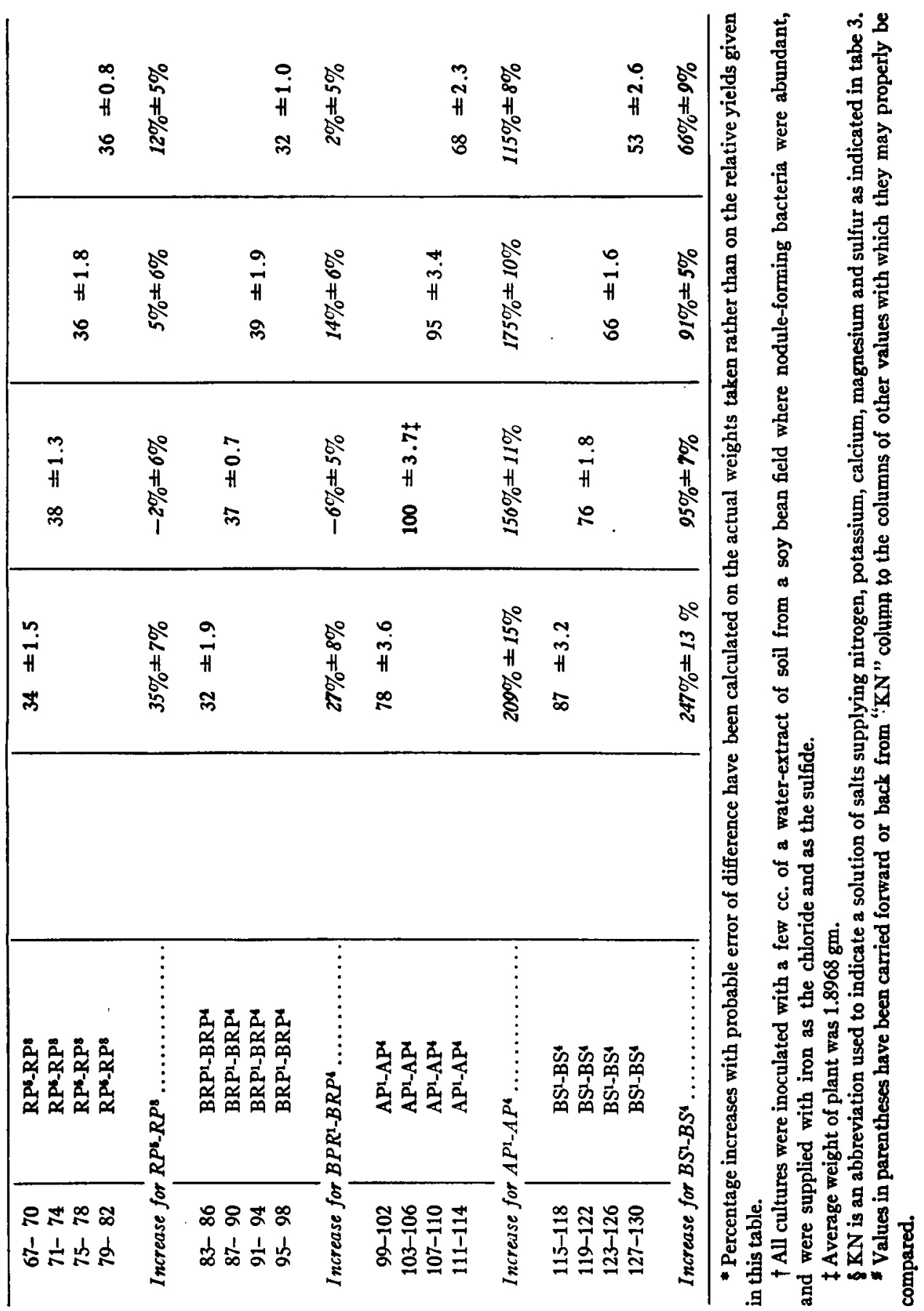


When used in addition to limestone or hydrated lime, neither "hydrophos" nor "thermophos" proved to be of more value than rock phosphate. The larger amounts of hydrated lime $\left(\mathrm{HL}^{5}-\mathrm{HL}^{8}\right)$ seem to have decreased plant growth, especially when used in addition to acid phosphate or basic slag. Cultures receiving acid phosphate except those to which the larger amounts of hydrated lime were added, produced two to four times as much growth as any other cultures except those treated with basic slag, while the corresponding cultures with basic slag produced one and two-thirds to two and one-third times as much growth as cultures treated with any other form of phosphorus except acid phosphate, comparing always those cultures which receive like treatment in addition to phosphorus. In no case with any of the phosphates used other than acid phosphate or basic slag, was the increase or decrease great enough or the probable error of difference small enough to indicate with any degree of certainty that the variation in yield from that of the corresponding culture without phosphorus was due to anything other than to individuality in plant growth.

The material prepared by simply burning and hydrating phosphatic limestone was not used with limestone sufficient to neutralize the soil acidity because it was thought that the phosphorus from this source would be more available in an acid soil. It is not probable that the difference in yield with and without limestone would have been greater than that for floats with and without limestone.

Sulfur inoculated with sulfur-oxidizing organisms, was added to six cultures with the hope that the acid produced would dissolve phosphorus and make it available. The amount added was 0.0522 gram per jar, equal to one-fifth the quantity of floats (RPl) with which $t$ was used in two of the cultures. None of the cultures so treated produced greater growth over the corresponding cultures without sulfur than may be accounted for by experimental error.

\section{Soil Culture, Series $B$.}

In addition to the sand cultures, another series of cultures was grown in soil. The soil was taken from the surface foot of a sassafras silt loam, from a field which had not been fertilized for 30 years or more and had not been under cultivation for a number of years. It contained 0.098 per cent of total $\mathrm{P}_{2} \mathrm{O}_{6}$ and had a lime requirement, according to the Veitch test, of 2000 pounds of $\mathrm{CaO}$ per $2,000,000$ pounds of soil. Loss on ignition was 6.13 per cent and its hydrogen ion concentration at the beginning of the experiment corresponded to a $\mathrm{pH}$ value between $\mathbf{5 . 5}$ and 5.9. Its water holding capacity was found to be 46.86 per cent of the weight of the dry soil and during the growth of the cultures the soil was kept near 57 per cent of its water holding capacity. During the first part of the experiment the cultures were weighed when water was added, but towards the end they were watered without weighing. 
Series B was soy beans of the Edna variety, four plants to a culture, grown from April 30 to July 2, 1921, in 2 gallon jars containing 7500 grams of air dry soil.

As in the sand culture series, acid phosphate was taken as the standard of phosphorus application, 400 pounds per $2,000,000$ pounds of soil being the rate of application. Applications of other phosphate fertilizers were such that the amount of phosphorus added equaled that of the acid phosphate applications.

One culture was left without fertilizer treatment of any kind while the others received combinations of lime and a fertilizer mixture supplying nitrogen and potassium. Each of the cultures was inoculated with the proper legume bacteria. Details as to the kind and amounts of salts used and also other details of treatment are given in footnotes to table 5 .

\section{Symbols used in table 5}

GL', GL', GL' = calcium carbonate (c.p.) used at rates of $1,000,2,000$ and 4,000 pounds of $\mathrm{CaO}$ per 2,000,000 pounds of soil respectively. The Veitch test showed 2,000 pounds of $\mathrm{CaO}$ to be necessary to neutralize the acidity of 2,000,000 pounds of the soil.

$M L 1, M L 2$ = magnesium carbonate (c.p.) used at rates equivalent to 1,000 and 2,000 pounds of $\mathrm{CaO}$ per $2,000,000$ pounds of soil.

$\left(\mathrm{CaSO}_{4}\right)^{1},\left(\mathrm{CaSO}_{4}\right)^{2}-$ calcium sulfate (c.p.) supplying $\mathrm{Ca}$ at rates equal to 1,000 and 2,000 pounds of $\mathrm{CaO}$ per 2,000,000 pounds of soil.

KN = potassium sulfate (c.p.) and sodium nitrate (c.p.) each used at the rate of 200 pounds per $2,000,000$ pounds of soil.

$\mathrm{K}=$ potassium sulfate (c.p.) used at the rate of 200 pounds per $2,000,000$ pounds of soil.

$\mathrm{NO}_{8}=$ sodium nitrate (c.p.) used at the rate of 200 pounds per $2,000,000$ pounds of soil.

$\mathrm{NH}_{4}=$ ammonium sulfate (c.p.) used at the rate of 155 pounds per acre supplying nitrogen at a rate equivalent to 200 pounds of sodium nitrate per $2,000,000$ pounds of soil.

HP = "hydrophos," phosphatic limestone burned ten hours, slaked with water while hot, pulverized to pass an 100-mesh sieve (23.85 per cent total $\mathrm{P}_{2} \mathrm{O}_{6}$ ) and used without further treatment at the rate of 298 pounds per acre supplying phosphorus at a rate equivalent to 400 pounds of acid phosphate per $2,000,000$ pounds of soil.

$A P=$ acid phosphate $\left(17.8\right.$ per cent total $\left.\mathrm{P}_{9} \mathrm{O}_{6}\right)$ used at the rate of 400 pounds per $2,000,000$ pounds of soil. Analysis showed the soil to contain .098 per cent total P205.

RP = floats $\left(34.1 \%\right.$ total $\left.\mathrm{P}_{8} \mathrm{O}_{6}\right)$ pulverized to pass an 100-mesh sieve and used at the rate of 208 pounds (equivalent to 400 pounds of acid phosphate) per $2,000,000$ pounds of soil.

OM = organic manure (fresh horse dung) used at the rate of ten tons per $2,000,000$ pounds of soil.

$\mathrm{KP}$ - potassium acid phosphate $\left(\mathrm{KH}_{2}\left(\mathrm{PO}_{4}\right)_{2}\right.$, c.p.) used at the rate of 3264 pounds per 2,000,000 pounds of soil.

$\mathrm{CaP}=$ calcium acid phosphate $\left(\mathrm{CaH}_{4}\left(\mathrm{PO}_{4}\right)_{2}, \mathrm{c} . \mathrm{p}.\right)$ used at the rate of 2568 pounds per acre, supplying $\mathrm{P}_{2} \mathrm{O}_{1}$ at $91.45 \%$ the rate of 3264 pounds of $\left.\mathrm{KH}_{2} \mathrm{PO}_{2}\right)_{2}$ and supplying $\mathrm{CaO}_{2} \mathrm{Ot}$ the rate of 615 pounds per acre, equivalent to 614 pounds of $\mathrm{CaO}$ per acre.

\section{Results of Series $B$}

The relative weights of dry tops for each treatment of series $B$ are brought together in table 5 along with the probable error for each of them determined on the weights of individual plants. As indicated in table 5 these figures are in some cases averages of two cultures and in others they are of single cultures. 


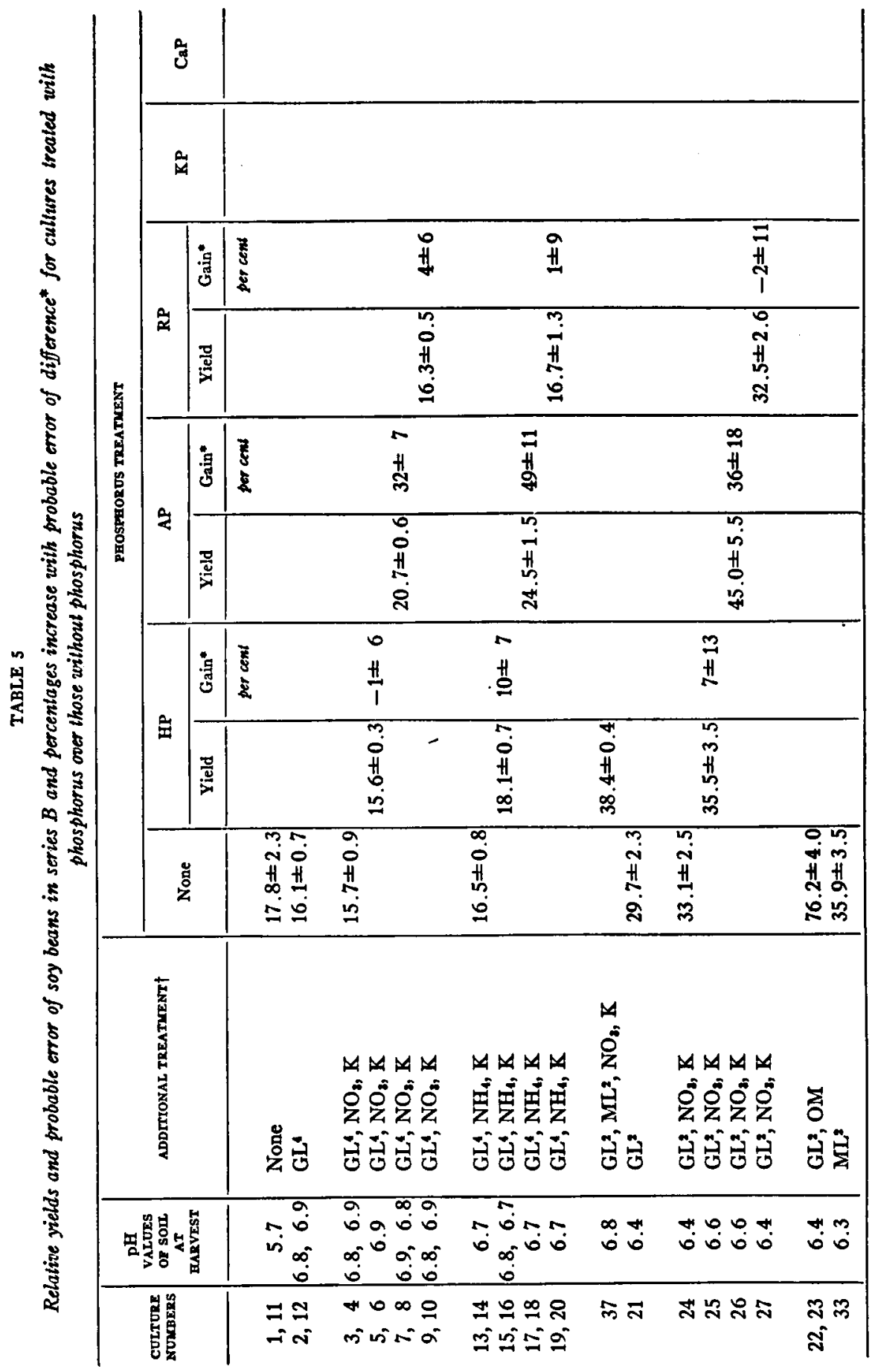




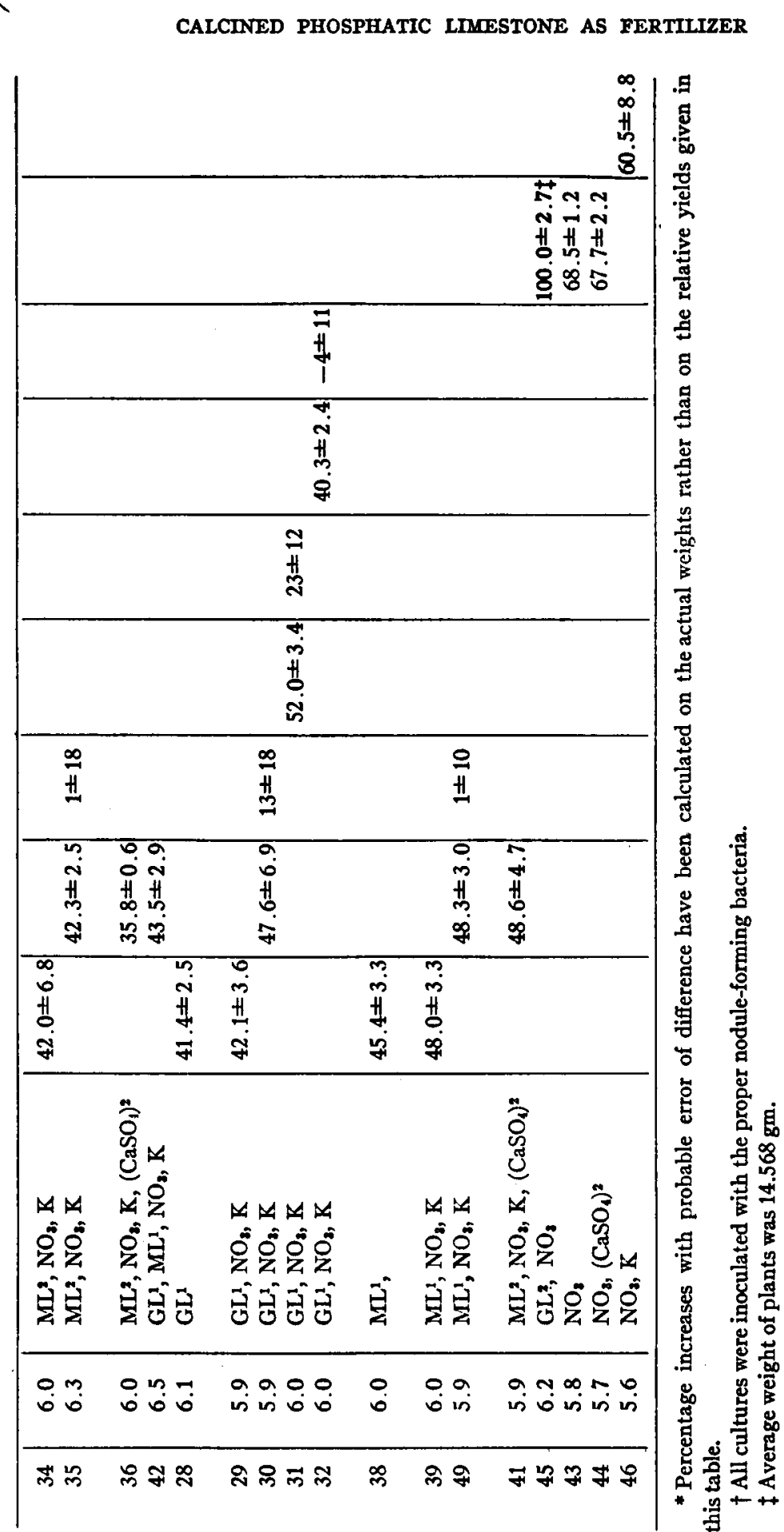


Percentage increase or decrease with probable error of difference has also been calculated on weights of individual plants. The $\mathrm{pH}$ values included in this table were determined on samples of soil taken from each jar at about harvest time.

The response which this soil shows to heavy applications of phosphorus is indicated by the weight of culture 45 , with 0.1623 per cent of $\mathrm{KH}_{2} \mathrm{PO}_{4}$, which produced the heaviest crop of all, and by the weights of cultures 43,44 and 46, also with large applications of phosphorus, which produced the next heaviest yields, excepting only cultures 22 and 23 which were heavily fertilized with organic manure.

As table 5 shows, there are six possible comparisons between cultures without phosphorus fertilizer and cultures receiving "hydrophos." There are four similar comparisons possible for the effect of rock phosphate. In these ten comparisons the relation between percentage increase and the corresponding probable error of difference is such that in only one case is there so much as an even chance that either "hydrophos" or rock phosphate used at rates equivalent to 400 pounds of acid phosphate per acre produced an increase in growth. Acid phosphate produced increases large enough to be beyond question of doubt.

\section{Barley Cultures, Series $C$}

A third series of cultures consisted of barley grown in soil from the same source as that used in series B. Acid phosphate was used in amounts equivalent to 200 and to 400 pounds per 2,000,000 pounds of soil and both "hydrophos" and floats were used in corresponding amounts. The results obtained agreed with those from series A and series B in showing a decided increase in growth from acid phosphate, but no decided effect from either "hydrophos" or rock phosphate. Figure 3 shows a few cultures from this series the treatment of which varied only in phosphate fertilizer.

\section{CONCLUSIONS}

1. Burned and hydrated phosphatic limestone is considerably inferior to acid phosphate as a fertilizer either in sand cultures or in soil cultures.

2. The amount of hydrated lime supplied by using burned phosphatic limestone in amounts corresponding to 400 pounds of acid phosphate to the acre is entirely ineffective in correcting the lime requirement of an acid soil.

3. Any advantage that burned and hydrated phosphatic limestone may show over phosphate rock is so slight that it may be accounted for by the fact that its iron and aluminum content is lower and is in less intimate contact with the tricalcium phosphate.

4. Pulverized phosphatic limestone is as valuable for soil treatment as are any of the phosphatic products obtained in this test from the burning of this limestone. 


\section{REFERENCES}

(1) Merroman, Mansriend 1913 A Text Book on the Method of Least Squares. Wiley and Sons, New York.

(2) Stoppant, E., aNd Volpato, V. 1921 Disintegration of mineral phosphates for fertilizer manufacture. In Chem. Abs., v. 15, no. 10, p. 1595. 


\section{PLATE 1}

Fic. 1. Phosphatic Limestone in a Phosphate Rock Mnge Near Columbia, Tennessee, after the Overlyme Soll and the Phosphate Rock had Been Removed

Fig 2. Sand Cultures prom Series a

Culture 107 with acid phosphate.

Culture 25 with burned and hydrated phosphatic limestone ("HP").

Culture 44 with the washed granular phosphate from the burned and hydrated phosphatic limestone ("TP")

Culture 62 with 100 -mesh floats

Culture 78 with 200-mesh floats

- Culture 123 with basic slag

Fic. 3. Barley Cultures in Soll prom Sertes C-Fertilizer Saits (KN) and also the Phosphates Added to the Soll yor a Previous Crop or Soy Brans

Culture 38 without phosphorus

Culture 41 without phosphorus

Culture 6 with "hydrophos" (HP").

Culture 16 with acid phosphate (AP')

Culture 25 with floats (RP')

Culture 34 with c.p. tricalcium phosphate ( $\left.\mathrm{PP}^{2}\right)$. 


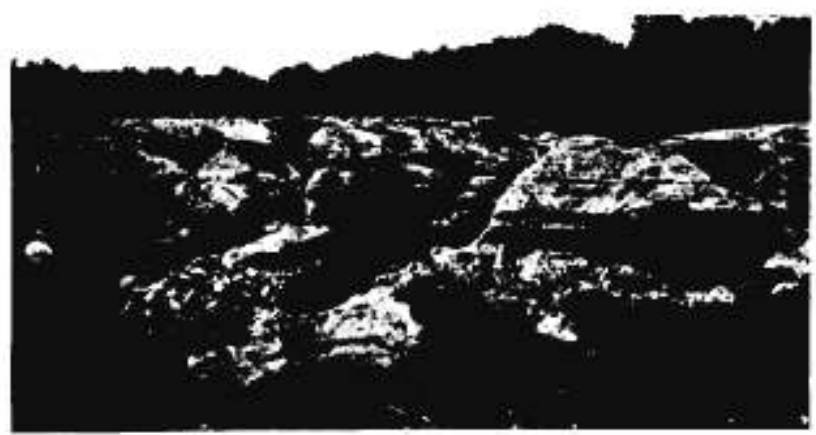

FIG. 1

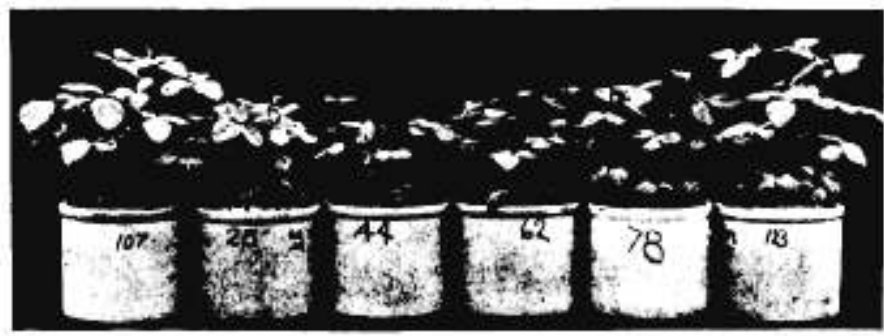

FIG. 2|

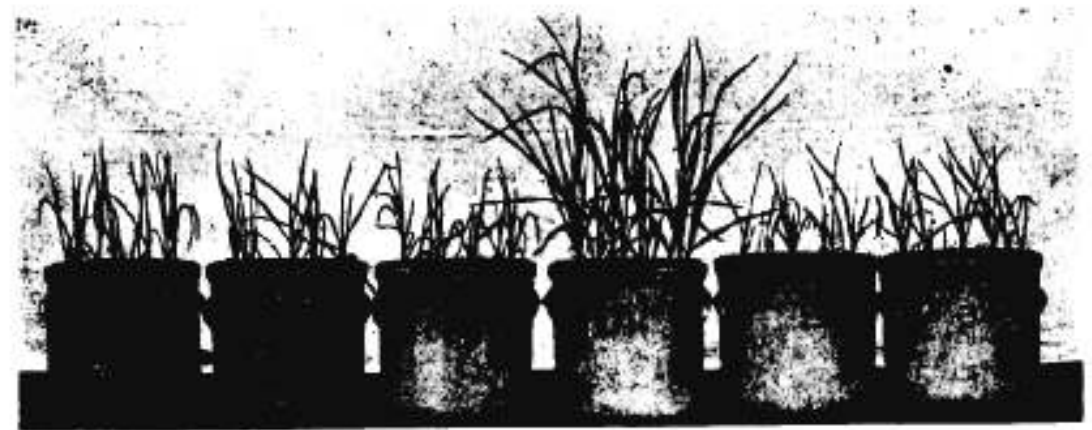

FIC. 3 